\title{
Enzymatic colouration with laccase and peroxidases: Recent progress
}

\author{
JIAJIA FU ${ }^{1,2}$, GIBSON S. NYANHONGO ${ }^{3}$, GEORG M. GÜBITZ ${ }^{3}$, \\ ARTUR CAVACO-PAULO ${ }^{4} \&$ SUYEON KIM ${ }^{5}$
}

${ }^{1}$ Key Laboratory of Science E Technology of Eco-textiles Ministry of Education, Fiangnan University, Wuxi, P.R. China, ${ }^{2}$ College of Textiles and Clothing, Fiangnan University, Wuxi, P.R. China, ${ }^{3}$ Institute of Environmental Biotechnology, Graz University of Technology, Petersgasse 12/1, Graz, Austria, ${ }^{4}$ Department of Textile Engineering, University of Minho, Guimarães, Portugal, and ${ }^{5}$ Sección Electricidad y Electrónica, Departamento de Ingeniería, Pontificia Universidad Católica del Perú, Lima

\begin{abstract}
Enzymes have received significant attention as alternative catalysts to chemical auxiliaries in textile processing. For example, laccases and peroxidises are promising alternatives for bleaching and denim stone washing processes. Similarly, the ability to oxidise different phenolic substrates and dye precusors resulting in the formation of different coloured polymeric molecules is being exploited for developing green chemistry dyeing processes. The enzymatic process is simpler than conventional coloration processes, giving economic and environmental benefits. In this review, the applications of laccase and peroxidise enzymes in dyeing processes of various textile meterials is discussed.
\end{abstract}

Keywords: Laccase, peroxidise, enzymatic colouration, polymerization, antioxidant

\section{Introduction}

Advances in enzymology and related areas of molecular biology and genetic engineering offer significant opportunities to develop novel enzyme-based processes (green chemistry technologies), representing a major step in environmentally friendly industrial development. The demand for application of enzymes in industry is increasing due to the need to overcome high consumption of energy and raw-materials as well as increased environmental concerns over the use and disposal of chemicals into landfills, water or the air during chemical processing. For this reason, enzyme applications have expanded to various fields, including the chemical, fuel, food, agricultural, paper, textile and cosmetic industrial sectors (Maciel et al. 2010).

This is particularly true in the textile industry. It is well known that conventional processes of dye production and colouration require high temperatures and pressure, have high consumption of alkali and unsafe chemical reagents, and release effluents to the environment, which can cause severe environmental pollution, damage to coloured materials and instruments and harm human health. This has driven the search for environmentally acceptable alternatives to chemical synthesis of dyes and colouration. As stereospecific natural biological catalysts, enzymes greatly reduce the reaction activation energy and thus lower process energy consumption (Kim 2009). Enzyme application in textile treatment can minimize not only the COD (chemical oxygen demand) and BOD (biological oxygen demand) in effluents, but also the amount of effluent. Moreover, enzymes are biodegradable and therefore considered as non-pollutive and self-cleaning materials. This review focuses on the new concept of enzyme assisted textile colouration by introduction of various functional polymers through enzymatic catalysis using laccases and peroxidases. The physicochemical and biological properties of specific enzymes are also introduced.

Correspondence: S. Kim, PhD, Sección Electricidad y Electrónica, Departamento de Ingeniería, Pontificia Universidad Católica del Perú, Av. Universitaria 1801, San Miguel, Lima 32, Perú. Tel:+511-626-2000. Fax:+511-626-2854. E-mail: sykim@det.uminho.pt 


\section{General biochemical properties and characteristics of oxidoreductase (laccase and peroxidase)}

\section{Laccase}

Laccases (EC 1.10.3.2) are multi-copper containing oxidoreductases mainly obtained from bacteria and fungi (Alcalde 2007; Araújo et al. 2008; Baldrian 2006; Campos et al. 2001b; Desai \& Nityanand 2011; Hoegger et al. 2006; Jeon et al. 2010; Kunamneni et al. 2008a; Mustafa et al. 2005; Pereira et al. 2005; Riva 2006; Zille 2005). Enzymes of this group were first described by Yoshida in 1883 based on the observation of rapid hardening of the latex from Japanese lacquer trees (Rhus vernicifera) in the presence of air (Call \& Mücke 1997; Gianfreda et al. 1999; Yoshida 1883) and named laccase 10 years later, after isolation and purification (Bertrand 1894). Since then, laccase activity has been found in other plants species (e.g. mango, mung bean, peach), certain prokaryotes (e.g. Azospirillum lipoferum) and various insects, with the most biotechnologically useful laccases being predominantly of fungal origin (e.g. Ascomycetes, Deuteromycetes, Basidiomycetes) (Baldrian 2006; Benfield et al. 1964; Claus 2003, 2004; Desai \& Nityanand 2011; Forte et al. 2010; Gianfreda et al. 1999; Kalmis et al. 2008; Kunamneni et al. 2008a). White-rot fungi from Basidiomycetes are the highest producers of laccases (Kunamneni et al. 2008a). Such widespread detection indicates that the laccase redox process is ubiquitous in nature.

Laccases are dimeric or tetrameric glycoproteins, containing four copper atoms per monomer bound to three redox sites T1 (blue copper centre), $\mathrm{T} 2$ and T3 $\mathrm{Cu}$ pair to coordinate at the active site of each enzyme molecule or functional unit (Dwivedi et al. 2011; Kunamneni et al. 2008b; Messerschmidt \& Huber 1990; Solomon et al. 1992, 1996; Yaropolov et al. 1994). Copper atoms differ from each other in their characteristic electronic paramagnetic resonance (EPR) signals (Dwivedi et al. 2011; Gianfreda et al. 1999; Zille 2005). In the T1 copper site, the substrate is oxidised and shows an intense electronic absorbance around $610 \mathrm{~nm}$ (Burton 2003; Maciel et al. 2010; Zille 2005). The colourless T2 copper site shows no absorption in the visible spectrum but is EPR detectable (Dwivedi et al. 2011; KoroljovaSkorobogat'ko et al. 1998; Leontievsky et al. 1997; Solomon et al. 1996; Zille 2005;). The other two belong to the diamagnetic spin-coupled copper-copper pair at the T3 site with a weak UV absorbance at $330 \mathrm{~nm}$ (Dwivedi et al. 2011; Zille 2005). The T2 and T3 copper atoms cluster to form a trinuclear site responsible for oxygen binding and reduction to water (shown in Figure 1) (Cole et al. 1990; Solomon et al. 1992; Zille 2005). The redox potential of laccases depends on the structure and properties of the copper centres. Generally, laccases from Basidiomycetes (especially, white-rot fungi) have a high-redox potential (Gutiérrez et al. 2006), whereas, laccases from bacteria and plants have a low-redox potential (Mikolasch \& Schauer 2009). Previous studies have indicated that the catalytic efficiency of laccases for some reducing substrates depends linearly on the redox potential of the T1 copper, showing the higher the redox potential of the T1 site is, the higher the catalytic efficiency of the laccase presents (Xu et al. 1996, 2000).

Laccases are able to catalyse monoelectronic oxidation with concomitant reduction of oxygen to water as the final by-product in a four-electron transfer process (Bourbonnais et al. 1997; Durán et al. 2002; Jeon et al. 2010; Kudanga et al. 2011; Kunamneni et al. 2008a; Morozova et al. 2007; Riva 2006; Robles et al. 2000; Thurston 1994; Xu 1996; Yaropolov et al. 1994). The mechanism of laccase catalysis involves the reduction of copper T1 by oxidising a substrate, internal electron transfer between the different copper types from copper T1 to the copper $\mathrm{T} 2$ and $\mathrm{T} 3$ trinuclear cluster, and the reduction of oxygen to water at the T2 and the T3 copper site (Messerschmidt 1994; Solomon et al. 1992; Thurston 1994; Yaropolov et al. 1994). Such

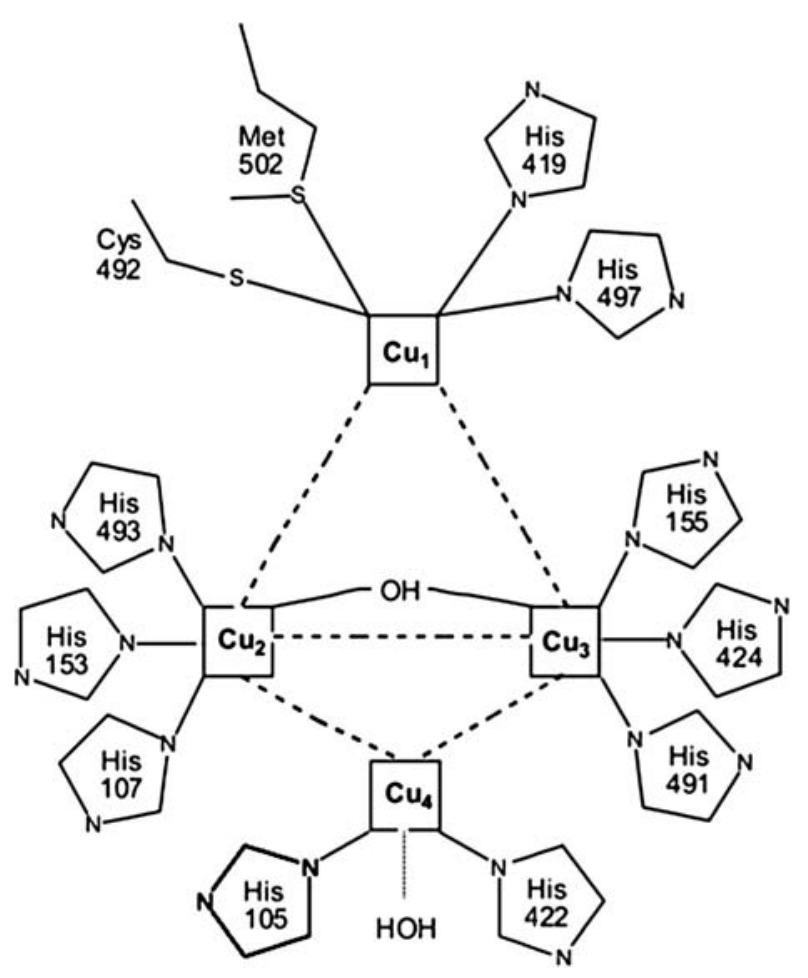

Figure 1. Copper centres of laccase (adapted from Claus 2004). 
oxidation gives rise to radicals capable of spontaneously rearranging and undergoing further fission of $\mathrm{C}-\mathrm{C}$ or $\mathrm{C}-\mathrm{O}$ bonds of the alkyl side chains, or to cleavage of aromatic rings, resulting in depolymerization, repolymerization, demethylation or quinone formation (Thurston 1994; Yaropolov et al. 1994; Flickinger \& Drew 1999; Kunamneni et al. 2008b). Thus, the main functions of laccases are briefly demonstrated as crosslinking of monomers (Claus 2004; Durán \& Esposito 2000), degradation of polymers (Claus 2004; Claus et al. 2004; Durán \& Esposito 2000) and ring cleavage of aromatics (Claus 2004; Kawai et al. 1999).

The large size of laccase (MW 70000) (Bourbonnais et al. 1997) makes it difficult to penetrate into substrates, meanwhile the relatively low redox potential limits laccase oxidation only for phenolic lignin fragments (Evans \& Hedger 2001; Kersten et al. 1990). However, the discovery of new and efficient mediators extend the effect of laccase to nonphenolic lignin units and also overcome the accessibility problem (Bourbonnais \& Paice 1990, 1992; Bourbonnais et al. 1997; Camarero et al. 2005; Crestini \& Agryropoulos 1998; Eggert et al. 1996a; Galli \& Gentili 2004; Hammel 1996; Hammel \& Moen 1991; Kudanga et al. 2011; Kuhad et al. 1997; Van Aken \& Agathos 2001, 2002). This is because a mediator is a small molecule that acts as a sort of 'electron shuttle' and is therefore able to penetrate to the inner part of polymers. In the laccase-mediator system (LMS), the mediator is first oxidised by laccase generating a strongly oxidising intermediate, the co-mediator (Med ox), and then diffuses away from the enzyme active site into the cell wall, and in turn oxidises any substrate inaccessible to laccase (shown in Figure 2) (Banci et al. 1999; Barreca et al. 2004).

An ideal redox mediator should be a good laccase substrate with cyclic redox conversion and its oxidised and reduced forms must be stable with no inhibition on enzymatic reaction (Johannes \& Majcherczyk 2000). The addition of redox-mediators, such as ABTS (2,2'-azino-bis (3-ethylbenz- thiazoline6-sulfonic acid), HBT (1-hydroxybenzo-triazole) or compounds secreted by lignolytic fungi, which transfer electrons between the enzymes and the substrates (Bourbonnais et al. 1995; Eggert et al. 1996b; Johannes \& Majcherczyk 2000; Reyes et al. 1999;

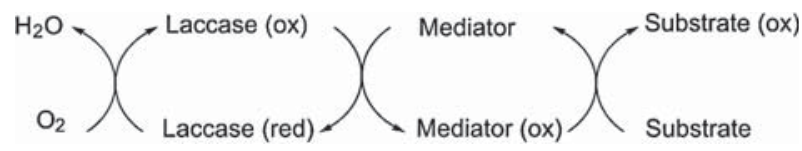

Figure 2. Catalytic cycle of a laccase-mediaator oxidation system (adapted from Banci et al. 1999).
Wong \& Yu 1999) can further expand the substrate specificity of laccases, which is already broad, ranging from various organic substances (e.g. ortho- and para-diphenols, aminophenols, methoxy-substituted monophenols, polyphenols, polyamines, aromatic amines, alkyl- and alkoxy-substituted anilines, lignins, syringaldazine, aryl diamines) to some inorganic ions (Bourbonnais et al. 1997; Gianfreda et al. 1999; Hoff et al. 1985; Kobayashi et al. 2001; Kobayashi \& Higashimura 2003; Li et al. 1999; Reinhammar 1984; Robles et al. 2000; Sakurai et al. 1992; Solomon et al. 1996; Thurston 1994; Yaropolov et al. 1994). Due to the high catalytic efficiency and broad oxidative capabilities, laccase has become attractive for many biotechnological and environmental applications, as compared to other conventional chemical or microbial catalysts (Desai \& Nityanand 2011; Durán et al. 2002; Dwivedi et al. 2011; Widsten \& Kandelbauer 2008). Additionally, substrate conversion using laccase coupled with small molecule redox shuttles is promising for the synthesis of new compounds (Pilz et al. 2003), offering new routes to colouration compounds for dyeing.

\section{Peroxidase}

Peroxidases (EC 1.11.1.7) are bifunctional oxidoreductase enzymes (Miranda et al. 2002; Mohamed et al. 2011) with molecular weights ranging from 35000 to 100000 (from 251 to 726 residues) (Banci 1997). They are able to catalyse the oxidation of a wide variety of organic and inorganic compounds in the presence of hydrogen peroxide but also produce reactive oxygen species (Dunford et al. 1976; Everse \& Everse 1991; Nigel 2004; Mohamed et al. 2011).

Due to their wide distribution among living organisms, multiple physiological roles, multifunctional reactivities and broad substrate specificities, peroxidases have attained a prominent position in biotechnology and associated research areas such as enzymology, biochemistry, medicine, genetics, physiology and histo- and cytochemistry (Azevedo et al. 2003; de Montellano \& Crab 1987; d'Ischia et al. 1991). Peroxidases have been found in plants, bacteria and fungi, and higher organisms (Battistuzzi et al. 2010; Reihmann \& Ritter 2006), and can be divided into three superfamilies: plant peroxidases, animal peroxidases and catalases according to their source and mode of action. Most peroxidases are glycoproteins containing $\mathrm{N}$-linked oligosaccharide chains (Dunford et al. 1976; Gray \& Montgomery 1997) and protoporphyrin IX (heme) as prosthetic group (Conesa et al. 2002). The structure of the active site in different superfamilies is similar, and they all use a similar mechanism involving formation of a 
two-equivalent oxidised (Compound I) intermediate (Gumiero et al. 2010).

Heme peroxidases catalyse the oxidation of a variety of substrates, most commonly small organic substrates, and are widely distributed in biological systems (Gumiero et al. 2010) but share the same catalytic cycle (shown in Figure 3) due to their strikingly similar active site structure. The catalytic cycle is based on three consecutive and distinct redox steps, involving two high-valent intermediates (Compound I and Compound II) (Banci 1997; Dunford 1999; English 1994; English \& Tsapralis 1995; Everse \& Everse 1991; Nakayama \& Amachi 1999; Smith \& Veitch 1998; Veitch \& Smith 2001). Initially, a molecule of hydrogen peroxide binds to the active site and undergoes a two-electron reduction to water and the formation of Compound I through oxidation of the enzyme. Compound I has an oxyferryl $(\mathrm{Fe}(\mathrm{IV})=\mathrm{O})$ centre and an organic cation radical located either on the heme or on a protein residue (Battistuzzi et al. 2010; Conesa et al. 2002). The cation radical then undergoes a one-electron reduction, oxidising one substrate molecule to give a substrate radical and forming Compound II. Finally, Compound II is reduced by a second substrate molecule to the resting ferric state (Banci 1997; Conesa et al. 2002; Dunford 1999; English 1994; English \& Tsapralis 1995; Everse \& Everse 1991; Nakayama \& Amachi 1999; Smith \& Veitch 1998; Veitch \& Smith 2001).

Among all peroxidases, horseradish peroxidase (HRP), a classical plant heme-containing enzyme from Armoracia rusticana roots (Kay et al. 1967; Nigel 2004; Ryan et al. 2006), has received special attention (Azevedo et al. 2003) due to its practical and commercial applications (Nigel 2004). Although the term

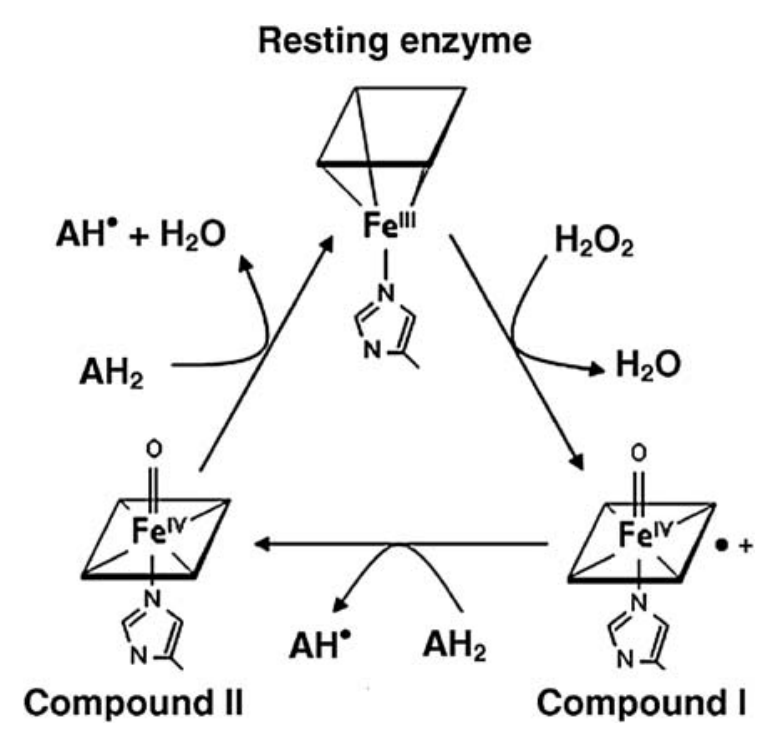

Figure 3. Catalytic cycle of peroxidase (adapted from Battistuzzi et al. 2010). 'peroxidase' came into use towards the end of the nineteenth century, research on peroxidase from the horseradish root and other plant sources was initiated by the work of Robert Chodat (1865-1934) and Alexei Nikolaevich Bach (1857-1946) at the University of Geneva during the early years of the twentieth century (Bach \& Chodat 1903). Horseradish peroxidases are most often used to catalyse an oxidative polymerization of electron-rich aromatic compounds like phenols, anilines and their derivative in the presence of peroxides like hydrogen peroxide, alkyl peroxides and benzyl peroxide (Reihmann \& Ritter 2006; Uyama \& Kobayashi 2006). HRP catalyses the one-electron oxidation of phenols by hydrogen peroxide as oxidising reagent to form the corresponding phenoxy radicals and two water molecules.

The phenoxy radicals go further to form polymers via subsequent recombination and radical transfer steps. The overall polymerization can therefore be written as shown in Figure 4 (Reihmann \& Ritter 2006):

Applications of laccase/peroxidase in textile and other areas

Enhancement of whiteness (Bio-bleaching) in cellulosic materials. Bleaching is the process of removing naturally-occurring coloured substances in fibres like cotton wax, fatty acid, colouring matter, albuminoids and mineral matter, amounting in all to $5 \%$ of the weight of material. The flavonoids are the substances mainly responsible for the natural colour of cotton. The natural colour on the fabrics can affect further finishing and dyeing processes leading to unexpected colour shades (Ardon et al. 1996; Hedin et al. 1992). Hydrogen peroxide is commonly applied in conventional bleaching processes, under alkaline condition and temperatures close to boiling. However, the radical reactions by hydrogen peroxide on the fibres can not only affect impurities fabrics but also the cellulosic components. That can result in severe damage of fabrics. Specific processes only targeting coloured impurities offer a practical alternative to the traditional bleaching process. Laccase, due to its ability to oxidise flavonoids (Araújo et al. 2008), can be applied in the bleaching of cellulosic materials (Kim et al. 2007c). However, the mechanism of laccase oxidation of natural compounds in fabrics to improve their whiteness is not well studied. Tzanov et al. (2003a) initially reported enhancement of the bleaching effect on cotton fabric using a low dosage of laccase over a short-time, batchwise or in a paddry processes prior to conventional peroxide bleaching. Also, Pererira et al. (2005) reported that laccases from a newly isolated strain of Trametes hirsuta were responsible for oxidation of the flavonoids morin, 


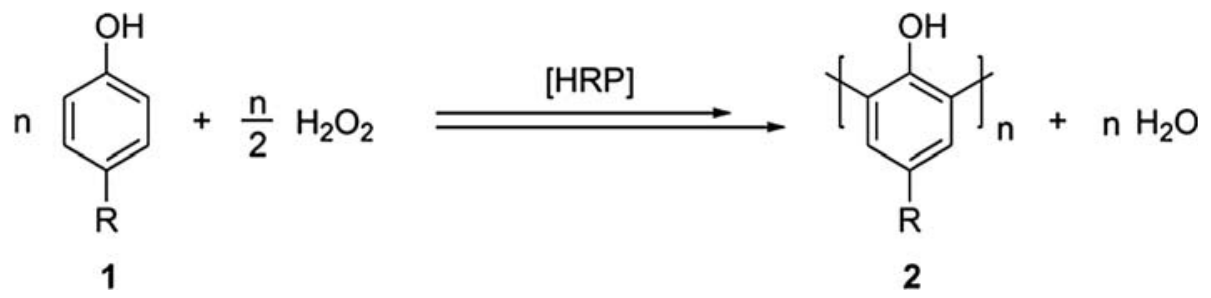

Figure 4. Polymerization of phenols catalyzed by horseradish peroxidase (HRP) (adapted from Reihmann \& Ritter 2006).

luteolin, rutin and quercetin and resulted in an increase of whiteness of cotton. More recently, ultrasound was used in the work of Basto et al. (2007) as a trial to intensify the enzymatic process by sonication to improve final whiteness of the fabrics.

Stonewashing and denim over dyeing. Stonewashing is generally known as denim washing where excessive amounts of indigo are removed from the fabrics. Cellulases can partially replace the role of pumice stones in the traditional process with an abrasive effect on the fibre surface producing the stonewashed look (Cavaco-Paulo et al. 1998). In addition, laccases can bleach indigo dyed denim fabrics to lighter shades (Campos et al. 2001b; Kunamneni et al. 2008b; Pazarloglu et al. 2005). However, the re-deposition of removed indigo dye on white weft yarns of denim fabrics (high indigo 'back-staining' on denim fabrics) is a major problem when removing the indigo dye trapped inside the cellulose fibre by the cooperative action of cellulases and mechanical action, which is mainly due to the tendency of cellulases to re-adsorb on the fabrics and bind to indigo (Cavaco-Paulo et al. 1998; Montazer \& Maryan 2008;). The degradation of indigo released during the stonewashing process could avoid the phenomenon of backstaining (Campos et al. 2001b). Laccases isolated from Polyporus sp. and Sclerotium rolfsii were found to degrade indigo on fabrics (Abadulla et al. 2000; Campos et al. 2001a). Those from Trametes hirsute and Sclerotium rolfsii in combination with redox-mediators caused various bleaching appearances in denim garments (Campos et al. 2001b), while the enzyme from batch cultures of Trametes versicolor can be used for denim washing without using a mediator, which is more effective than commercial laccase (obtained from recombinant Aspergillus niger, Novo Nordisk, Denmark) with a mediator (Pazarloglu et al. 2005). Recent investigations showed that laccases along with cellulases reduced the activity of neutral cellulases, and fibre damage was limited to the outer fibres with inner fibres remaining unaffected (Montazer \& Maryan 2008). The co-application of laccase with cellulase increased the lightness and decreased the staining on both the back of the garment and white pocket. Laccase decomposes the removed indigo during stone washing and in a concentration dependent manner, back-staining decreases (Maryan \& Montazer 2009). There are already some successful industrial applications of laccases in denim finishing, for example, DeniLite ${ }^{\mathrm{TM}}$, DeniLiteII $^{\mathrm{TM}}$, Zylite, ECOSTONE®LCC 10, PrimaGreen EcoFade LT100, etc. (AB Enzymes 2011; Couto \& Toca-Herrera, 2006).

The over-dyeing of denim, achieved by a further dyeing step, primarily dyes the fill yarn of the desized denim but also imparts some degree of dyeing to the previously dyed warp yarn, which can bring in new shades on textiles. Polymers formed by enzymatic polymerization have drawn considerable attention for application as 'dyes' in the denim overdyeing process. US Pat. No.5925148 (Barfoed \& Kirk 1999) claimed an enzymatic method for overdyeing warp dyed denim textiles, in which a hydrogen peroxide source or at least one enzyme exhibiting peroxidase activity and/or oxidase activity was employed for overdyeing fabrics and articles. Recently, Guimarães et al. (2011) adopted laccase from the ascomycete Myceliophthora thermophila as a catalyst to oxidise the polymerization 'in situ' of catechol and catechin, and the enzyme-generated polymers were capable to over dyeing the denims. Different colours were acquired based on the phenolic used, ranging from brown to green-yellow for catechol and catechin, respectively. Such enzyme-based overdyeing processes have launched new approaches for denim overdyeing with the same level of durability as obtained with direct dyes, at the same time increasing the fabric's hydrophobicity.

\section{Stain removal in laundry}

A peroxidase-based system for the inhibition of dye transfer during washing with laundry detergents was developed by Conrad et al. (1997). The mechanism of dye-transfer inhibition by peroxidases involves oxidation and decolourisation of released dyes. To enhance the dye decolourisation ability of the enzymes, phenothiazine-10-propionic acid was used as a mediator. The peroxidases 


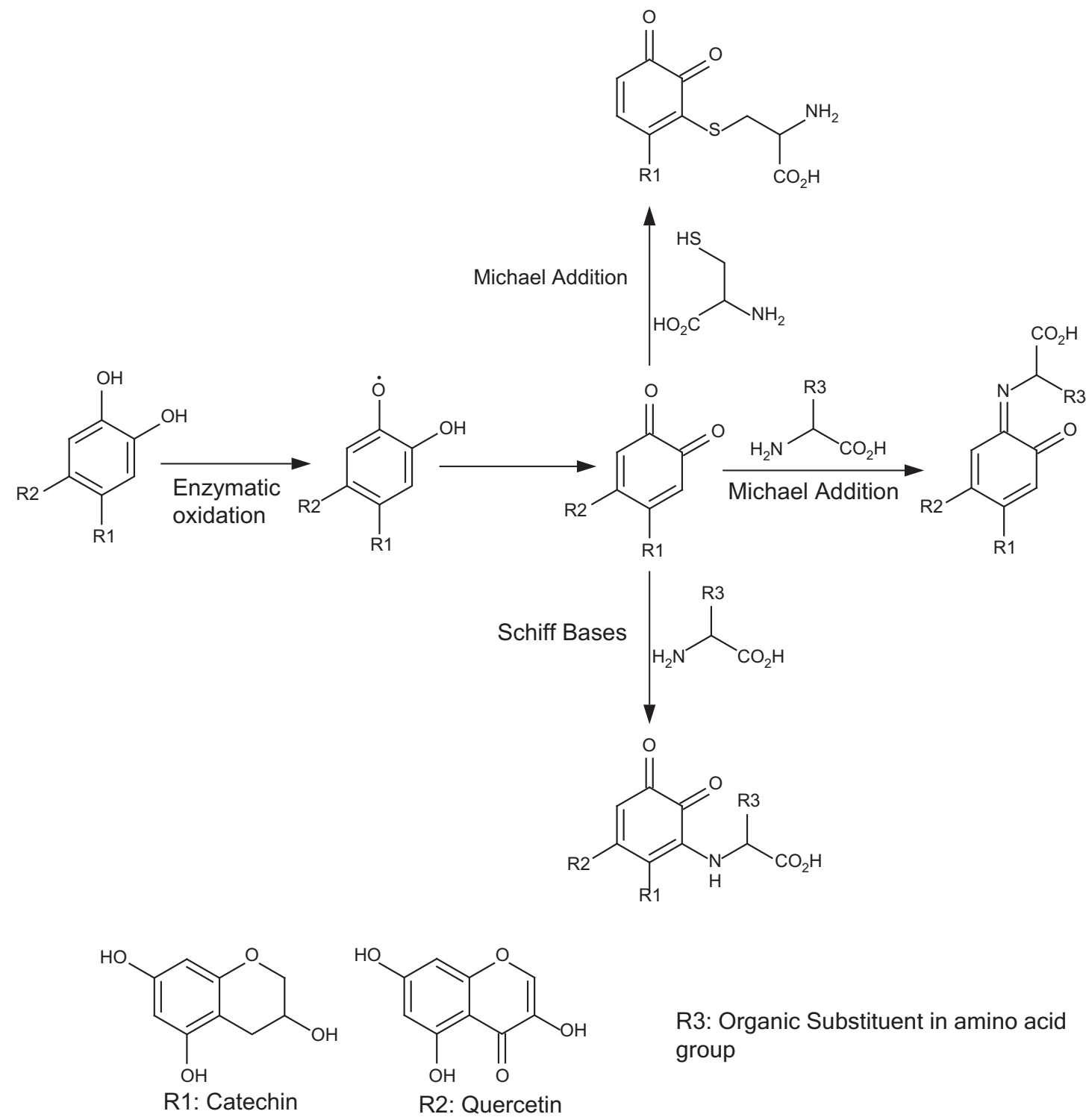

Figure 5. Schematic representation of enzymatic and non-enzymatic conjugation of flavonoids and reactive amino acids (adapted from Kim \& Cavaco-Paulo 2011).

oxidise phenothiazine-10-propionic acid to a highly reactive species responsible for oxidising and decolourising dyes in solution. A comparison of enzymatic and non-enzymatic dye-transfer inhibition systems showed that the enzymatic method is, in many cases, more effective than the nonenzymatic method (Conrad et al. 1997).

\section{Dye synthesis through oxidative polymerization}

The enzymatic polymerization phenomenon can be described as the synthesis of polymers 'in vitro' via non-biosynthetic pathways, catalysed by enzymes (Reihmann \& Ritter 2006). Since 1985, enzymatic oxidative polymerization of aromatic compounds has been widely investigated and anticipated to be an alternative method for the production of conventional phenolic resins, which typically involves the use of toxic formaldehyde (Aktas et al. 2000). Enzyme catalysis introduces the possibility of 'Green polymer chemistry' (Kumar et al. 2005; Reihmann \& Ritter 2006).

The principal mechanism of both peroxidases and laccases is one electron oxidation of phenolic compound to form phenoxy radicals using an oxidising reagent. However, the main difference between peroxidases and laccases is the type of oxidising agent, which is hydrogen peroxide and oxygen, respectively. The phenoxy radical may react with a second radical to form $o$-quinones, which are highly reactive electrophilic molecules and further spontaneously polymerize in a non-enzymatic pathway (Figure 5) (Amić et al. 2003; Uyama \& Kobayashi 2002). 
Phenolic polymers require specific functional properties of molecular weight, dispersity, degree of crosslinking, crystallinity, and inter- and intramolecular bonding (Aktas et al. 2000). Laccases and peroxidises are able to catalyse the transformation of phenol derivatives through an oxidative coupling reaction, resulting in the formation of less soluble and high molecular weight polymer compounds (Gianfreda et al. 2003). The polymerization of phenols catalysed by horseradish peroxidase (HRP) is fairly well understood based on published research (Adam et al. 1999; Hewson \& Dunford 1976a, b; Poulos 1993; Van Deurzen et al. 1997). The oxidation of aromatic electron donors in the presence of peroxide is an important step in peroxidise catalysed synthesis (Reihmann \& Ritter 2006; Tawaki et al. 2005). Peroxidases are able to yield chromogenic products and show relatively good stability characteristics (Worthington 2011).

Compared with peroxidases, the range of laccase substrates is very wide. Basically, any substrate possessing characteristics similar to $p$-diphenol will be oxidised by laccases. Moreover a few fungal laccases can oxidise monophenols such as cresol and some are able to oxidise ascorbic acid (Mayer \& Staples 2002). Using oxygen as an oxidation reagent and having a wide range of substrates is a valuable feature of laccase applications.

Forte et al. (2010) and Pogni et al. (2010) applied laccase from Cerrena unicolour to catalyse the one step bioconversion of 3-amino-4-hydroxybenzensulfonic acid into a water soluble phenoxazine dye having the structure of 2-amino-3-oxo-3H-phenoxazine-8-sulfonic acid. The initial mixture changed from yellow ochre to red. They claimed that the biocatalytic system offered eco-sustainable synthesis of complex polymers.

Mustafa et al. (2005) used the laccase oxidation of ferulic acid in a biphasic hydro-organic medium containing well-mixed ethyl acetate and sodium phosphate buffer and obtained intermediate stable yellow coloured products from the organic phase, with the ability to bind to macromolecules like pectin, hemicellulose etc (Craven et al. 1981; Taylor \& Clydesdale 1987a, b). Normally, when the laccase oxidation of phenolic and polyphenolic compounds (ferulic acid, gallic acid, caffeic acid and catechin) takes place in aqueous medium, the colour of the oxidation products goes from an intermediate yellow, green or orange to a final brown hue. However, the presence of an organic solvent in the reaction medium decreased both the laccase activity and nonenzymatic reaction rates, resulting in a major improvement in stability of the intermediate products. Therefore, the laccase-based synthesis of colorants may be expanded to other phenolic and polyphenolic compounds with this medium. In addition, a biphasic hydro-organic medium helped the preven- tion of browning and increased product solubility. The authors claimed an improved control of polymer synthesis. Recently, Polak and Jarosz-Wilkolazka (2010) tried to apply immobilized white rot fungal strains as cheaper industrial-grade biocatalysts for dye synthesis. Such biomass was able to catalyse the transformation of benzene and naphthalene derivatives and generate stable and non-toxic polymers with good dyeing properties, highlighting the possibility to replace isolated enzymes by fungal biomass to transform precursors into dyes in a more efficient and simple way (Polak \& Jarosz-Wilkolazka 2010). Enaud et al. (2010) synthesized a sulfonic azoanthraquinone through the coupling of aromatic amine monomers in the presence of the Perenniporia ochroleuca MUCL 41114 laccase, Laccase Acid Red 1 (LAR1). Such enzymatically created dyes were not mutagenic and showed lower toxicity than other commercial red dyes. A crude preparation of this new acid eco-colourant could be used directly and demonstrated good dyeing properties on polyamide. This work opens the way to safe and environmentally friendly routes to azo dye biosynthesis. Horseradish peroxidase (HRP) and soybean peroxidase (SBP) can also produce polymers from the flavonoids quercetin, rutin and catechin in the presence of $\mathrm{H}_{2} \mathrm{O}_{2}$ (Lorenzo et al. 2002).

\section{Laccase and peroxidase based colouration}

The first notable activity of heme peroxidases that led to their discovery was the observation by Planche in 1810 of their ability to catalyse the formation of a beautiful blue colour when a tincture of gaiac resin came into contact with fresh horseradish root, long before the enzyme was known (Nyanhongo et al. 2010). Similarly with respect to laccases, Chinese lacquer artwork from more than 6000 years ago reveals the use of laccase (Hüttermann et al. 2001). Recently, there has been growing interest in using these oxidative enzymes to improve the aesthetic look of fabrics. Dyes are colorants applied to textile substrates in a molecularly dispersed form (AATCC 1997, 375). Colour is derived from the conjugated double bonds in the molecular structure of the dyes (Clifford 1986; Bille \& Phyllis 1997). The dyes which are mainly used are classified as azoic dyes (naphthol dyes), direct dyes, vat dyes, sulphur dyes and reactive dyes (Bille \& Phyllis 1997). Different dyes are appropriate for the requirements for dyeing various substrates. The enzymatically polymerized phenolic compounds with high molecular weight are less soluble (Gianfreda et al. 2003) and tend to have a characteristic colour attributed to the formation of a large conjugated structure along the main chain (Shin 
et al. 2001), which offers great potential for application in colouration. The enzymatically produced polyphenols generally possess mixed structures with phenylene and oxyphenylene units resulting from the $\mathrm{C}-\mathrm{C}$ and $\mathrm{C}-\mathrm{O}$ coupling of phenols, respectively (Mita et al. 2003). Such enzyme-catalysed polymerization for polymer production is regarded as an 'environmentally friendly' synthetic process (Kobayashi et al. 2001) for colorant production.

\section{Colouration of cellulosic fibres (cotton and flax)}

In situ direct colouration on cellulosic materials. Fixation of dye molecules ' in situ' generated on the fibre surface can take place when a decrease in solubility their release during wet processing (Hadzhiyska et al. 2006). The key to achieving higher dye fixation on cellulosic materials depends on suitable molecular reations of dye precursors for enzymatic coupling (Hadzhiyska et al. 2006). Generally, enzymatic oxidation of dye intermediates dominantly leads to homo-molecular reactions at equimolar ratios of precursors. However, the higher the concentration of compounds that can transform into less soluble products upon laccase oxidation, the higher the fixation that may be achieved (Hadzhiyska et al. 2006). It is reported that increasing the concentration of phenol component benefits oxidative selfpolymerization into less soluble products (Aktas \& Tanyolac 2003; David et al. 1996; Dubey et al. 1998). Tzanov and coworkers have undertaken a series of studies on laccase-assisted dyeing of cotton since 2006, and demonstrated for the first time a permanent colouration of cotton fabrics with polymeric dyes generated in situ by oxidative coupling of 1-hydroxyphenol (catechol) and colourless 2,5diaminobenzenesulfonic acid (2,5-DABSA) in the presence of laccase (Calafell et al. 2007; Hadzhiyska et al. 2006). With an excess of catechol, the crosscoupling occurs in higher yield (Calafell et al. 2007). They suggested that at least four-fold excess of catechol was required for satisfactory dye fixation on cotton and proposed the reaction pathway for the laccase-catalysed oxidative coupling of the reagents shown in Figure 6. Laccase catalysed the conversion of catechol to highly reactive quinone species which undergo homo-molecular $\mathrm{C}-\mathrm{O}-\mathrm{C}$ coupling, and then non-enzymatic $\mathrm{C}-\mathrm{N}$ coupling with 2,5-DABSA took place through 1,4 nucleophilic addition of the latter to the quinoid rings (Calafell et al. 2007).

Non-toxic and non-harmful phenolic substrates such as flavonoids (rutin, morin and quercetin) have been used to coat and colourise cotton and flax fabrics. The laccase-oxidised flavonoids can graft onto the surface of the cotton and provide a yellow to brown colour of different colour strength, depending on the type of external flavonoids used and the reaction conditions (Kim et al. 2007a). Rutin flavonoids gave poor colour appearance on the surface of cotton fabric in the presence of laccase compared with morin and quercetin (Kim 2009) since the oxidation rate of rutin is lower than the other flavonoids (Friedman 1996) and the aqueous solubility of the enzyme-catalysed poly(rutin) reduced the chance for coupling to the cellulosic fibre surface (Kim 2009). Rinsing and washing conditions also influenced the colour visual inspection, and a remarkable colour vanish was detected in a high temperature process (Kim 2009). The washing and friction fastness test of flavonoid colourised cotton showed satisfactory results confirming the feasibility of this new and promising colouration technique (Kim 2009). Moreover, their application on the surface of fabrics introduces new functions on the fabrics such as antioxidant and antimicrobial properties, and therefore, increasing their potential.

Significantly, for all flavonoids tested, a higher increase in colour appearance and superior colour fastness was obtained when laccase treatment was carried out in the presence of scoured cotton fibres, rather than the scoured/bleached fibres (Kim et al. 2007a). Similar results were obtained in the colouration of flax fabrics with polymerized flavonoids. The scoured flax fabrics gave better colour strength and colour fixation in comparison with scoured and bleached fabrics (Kim 2009). Natural flavonoids present in cotton and flax may serve as grafting points or anchors to attach the intermediates (quinones) formed during oxidation by laccase (Friedman 1996; Makris \& Rossiter 2002), promoting colouration. However, the traditional bleaching pretreatment of cotton removes these natural flavonoids from cotton and flax. Elimination of the bleaching treatment results in savings of chemicals, water, energy, giving an environmentally friendly textile process (Kim et al. 2007a). Flax is thought to have a better affinity for oxidised flavonoids due to the higher quantity of lignin compounds on its surface compared with cotton (Kim 2009). A high temperature and the presence of salt improved polymer absorption onto the flax fabrics. Compared to morin, the quercetin flavonoid is more effective for colouration of flax fabrics. However, considerable colour vanished during the washing processes since the newly incorporated polymers had not deeply penetrated through the fibre structure and no strong covalent bonds were formed between the fibre and oxidised compounds, leading to a poor affinity (Kim 2009; Kim et al. 2009). In addition, polymers from laccase-catalysed polymerization of lignosulfonates were applied on the lignin-containing surface of flax fibre. However, the affinity of the resulting polymers towards the fibres was low since their high molecular weight 


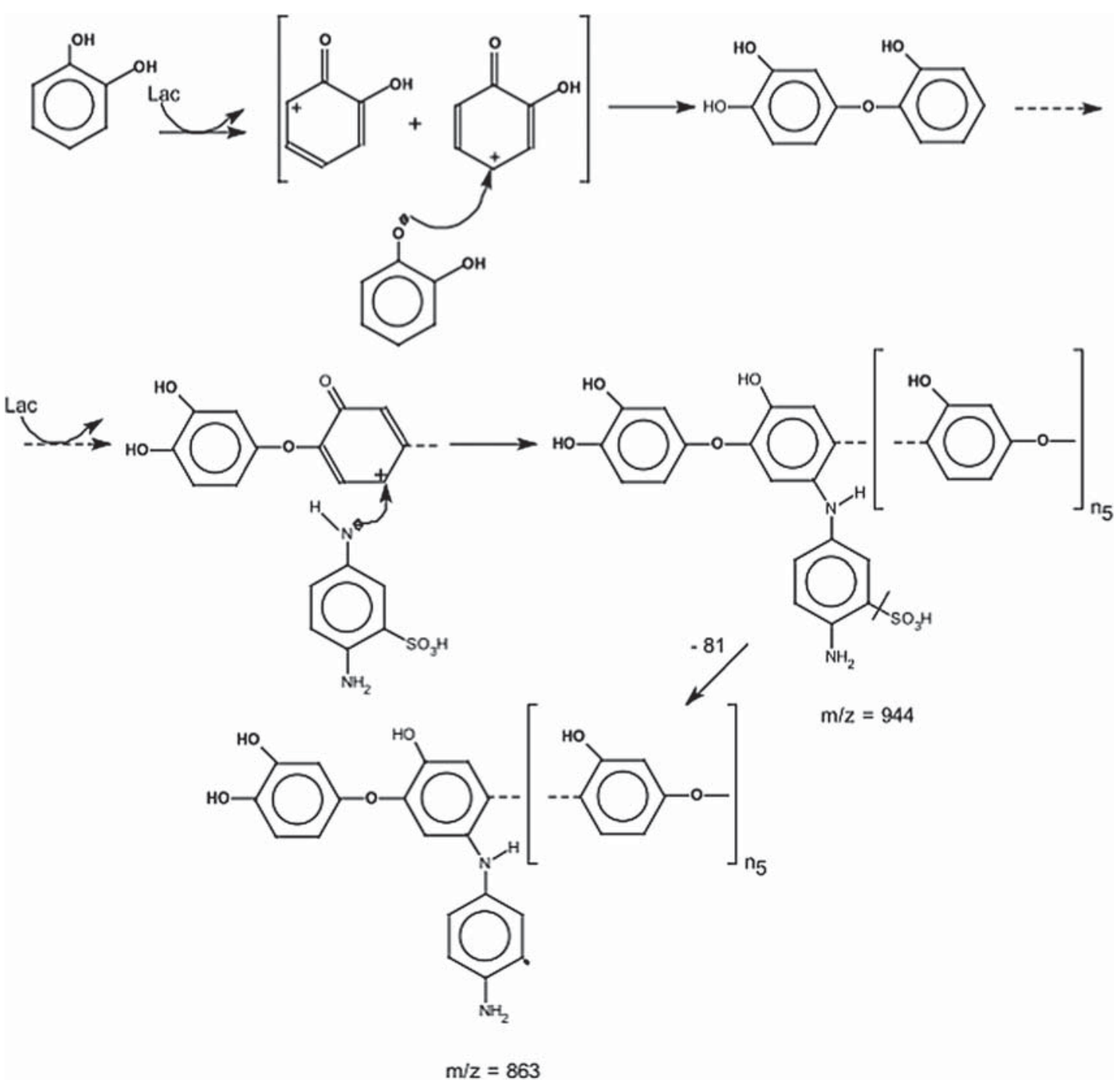

Figure 6. Proposed reaction pathway for laccase-catalyzed oxidative cross-coupling of 2,5-DABSA and catechol, and splitting pattern of the resulting product identified by MALDI-TOF MS (Adapted from Calafell et al. 2007).

affected interaction with the fibre structures. Therefore, the colour strength level was not so satisfactory (Kim 2009). In very recent work, polyoxometalates (POMs), namely $\mathrm{K}_{5}\left[\mathrm{SiW}_{11} \mathrm{~V}^{\mathrm{V}} \mathrm{O}_{40}\right] \cdot 11 \mathrm{H}_{2} \mathrm{O}$ and $\mathrm{H}_{5}\left[\mathrm{PMo}_{10} \mathrm{~V}_{2} \mathrm{O}_{40}\right] \cdot 13 \mathrm{H}_{2} \mathrm{O}$, were employed as inorganic mediators in the laccase-oxidative polymerization reaction to form a relatively high molecular weight polycatechol. The polymers synthesized by the laccase-mediator system allowed better colour fixation and colour resistance for flax compared to that obtained by conventional synthesis with laccase solely or with addition of an organic mediator (1-hydroxybenzotriazole) (Kim et al. 2011).

\section{Preparations of cellulosic fabrics for improving} polymer affinity

A major constraint for enzymatic colouration of cellulosic materials is the lack of affinity between the laccase-generated dyes and cellulosic materials, since no chemical bonding occurs. Various surface modification techniques like aminisation, pre-oxidation, cationisation, etc. have been employed to improve cellulose fibre-matrix adhesion (Tsubokawa et al. 2000; Zhou et al. 2005). These functional groups have chemical affinity to enzymatically produced polymers thus enhancing 'dyeability' (Chhagani et al. 2000; Mohorcic et al. 2004).

Based on its relatively low cost and wide ulitilization as a dye in the textile industry, Reactive Black 5 dye (RB5), a di-azo vinyl sulphonic dye, is normally adopted for aminisation (Mohorcic et al. 2004). Initially, RB 5 is covalently attached onto the cellulose fabric via a nucleophilic addition reaction (Chhagani et al. 2000) and then covalently attached RB5 molecules are chemically reduced to form aminic functional groups on the fabric surface (Chhagani et al. 2000; Kim et al. 2007b) as shown in Figure 7. 


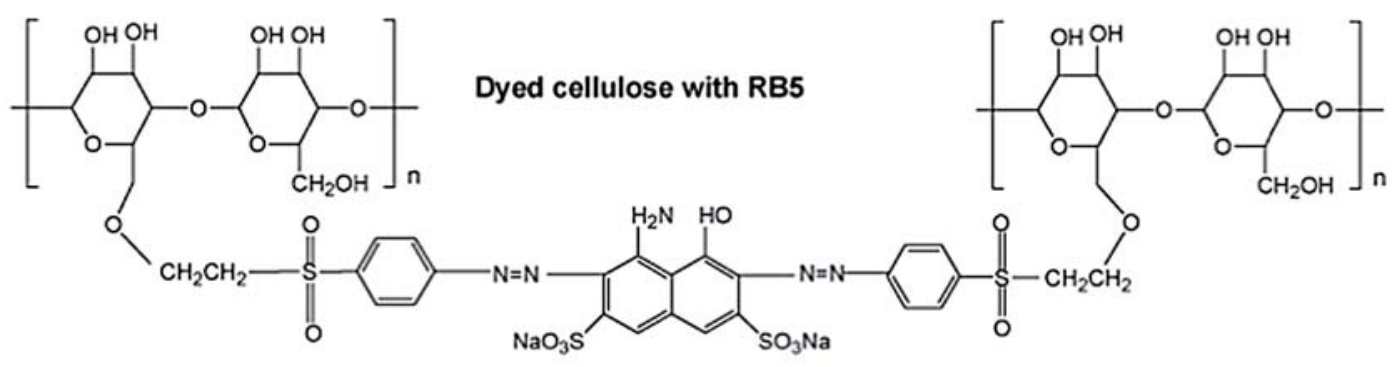

Reduction with sodium hydrosulphite

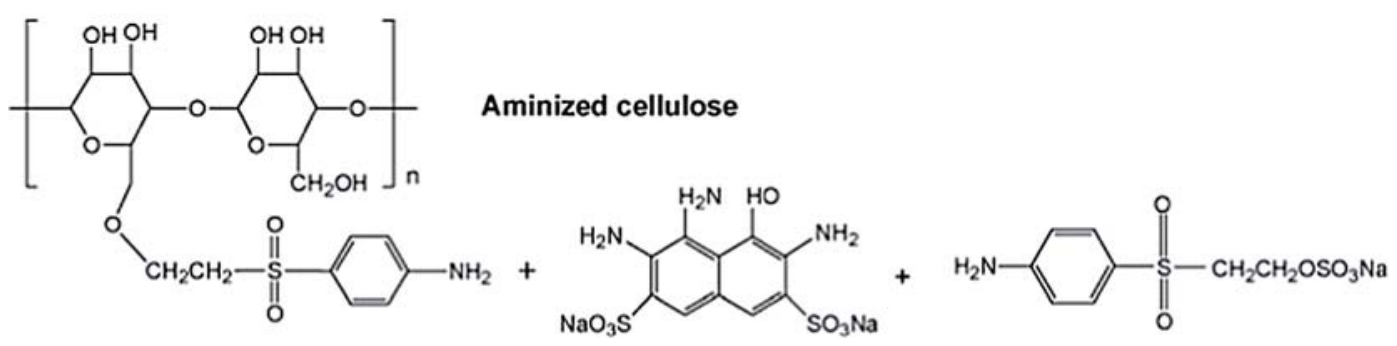

Figure 7. Mechanisms of chemical-reductive cellulose funcitionalization (adapted from Kim et al., 2007b).

Reduction of the two azo groups of RB5 produces three compounds containing amino groups: one compound covalently linked to cellulose and the other two dissolving in water. Decolorisation of the fabric can be observed during the reduction process, since the reduction of azo bonds resulted the formation of non-colourful amine groups. The amino groups on the cellulose can be exploited for coupling polyphenols obtained through enzymatic oxidation (Kim et al. 2007b). Compared with unfunctionalised cotton fibres, the aminised cotton fibres develop a much darker-brown colour after coating 'in situ' with laccase-synthesised polycatechol, which reflects the high level of coupling sites on the functionalized surface (Kim 2009). Meanwhile, coated functionalized-cellulose showed greater resistance to cellulase hydrolysis since the polymeric network on the fibre surface can sterically block the binding activity of cellulase (Kim 2009; Kim et al. 2007b).

Blanco et al. (2009) examined tosylation of the surface of cotton fabrics with subsequent amino group introduction with 2,5-DABSA through nucleophilic displacement of the tosyl groups in a quantitatively controlled way. The aminised cotton showed about $20 \%$ enhancement in dyeability compared to the unmodified fabric and allowed up to $95 \%$ pigment fixation on the fabric in the laccase catalysed process for fibres colouration.

Recently, Silva et al. (2011) described the application of natural compounds for aminization, using chitosan. In the presence of laccase, the amino functional groups of chitosan can covalently link with unbleached flax fabrics previously oxidised with laccase. The pre-oxidation of flax fabrics using laccase might develop grafting points for chitosan attachment by oxidation of natural phenolic compounds in flax to introduce reactive sites. The previously laccase-oxidised flax fabric had enhanced washing durability and higher grafting levels on the surface and, thus had a higher concentration of catechin polymers grafted onto the surface giving higher colour strength (Silva et al. 2011). In the study of Kim and Cavaco-Paulo (2011), the cationisation of flax fabrics using a polyanion was introduced for modification of flax fabrics by anchoring of protein-flavonoid conjugates produced by laccase catalysis. The cationised fabrics reacted with protein-flavonoid conjugates through strong ionic interactions. In the reaction medium, the proteins are negatively charged at $\mathrm{pH} 7.4$ with high affinity for the cationised surface of fabrics. The conjugates onto fibres had acceptable durability in terms of washing resistance and the surface became hydrophilic when $\alpha$-casein-catechin was applied (lower contact angle $48^{\circ}$ ). The final products with new colour generation and antioxidant activity $(>93 \%)$ were obtained by anchoring the protein-flavonoid conjugates onto flax fibres.

In addition to chemical pre-modification, mechanical agitation can also greatly influence the affinity of coloured polymers. Strong vertical agitation promotes the breakage of filaments on fibre 
surfaces increasing the accessible surface area for attachment of polymerized flavonoids (Kim 2009).

\section{Dyeing of keratinous fibres (wool and hair)}

Wool and hair are the most common keratinous fibres in textile and cosmetic applications, respectively. Enzymes like laccase or horseradish peroxidase can be applied for their colouration. The enzymatic dyeing process, when carried out at a mild $\mathrm{pH}$ and low temperature does not damage keratinous fabric, is an economically and environmentally attractive alternative to the conventional process (Tzanov et al. 2003b; Zille 2005).

Wool dyeing. Characteristic colours are determined by the use of different phenolic compounds for the enzymatic dyeing, such as hydroquinone (brownblacks), catechol (greys), dopamine (greys), guaiacol (colourless) and ferulic acid (yellows) after treatment with HRP (Shin et al. 2001). Shin et al. (2001) found that wool fabric previously treated with hydroquinone and ferulic acid can be coloured by laccase (or HRP), in which the hydroquinone on the fabric was enzymatically oxidised, forming dimers, oligomers and polymers. The colour depth of enzymatically dyed wool fabrics could be adjusted by the amount of hydroquinone previously added to the wool fabric. Mordant processing with chromium compounds and boiling under acidic conditions assisted the strong fixation of the coloured hydroquinone and ferulic acid derivatives to the wool fabrics.

Later, Tzanov et al. (2003b) and Zille (2005) optimized a novel laccase-assisted wool dyeing process performed in a dye bath using a dye precursor (2,5-diaminobenzenesulfonic acid) and dye modifiers (catechol and resorcinol) and laccase, without any dyeing auxiliaries. Varying the concentration of the modifiers and the time of laccase treatment generated different hues and depths of shades on the wool fabric. The wool fabrics dyed with catechol (modifier) showed redder and bluer colours, while the fabric dyed with resorcinol gave yellower and greener colours. The highest colouration value for catechol was achieved at the highest concentration of modifier, laccase amount and dyeing time, while the highest colouration value for resorcinol was attained at the highest concentration of laccase and dyeing time but lowest concentration of modifier. It was pointed out that the duration of the enzymatic reaction appeared to be the most important factor in the dyeing process. Darker colouration of the wool fabric could be achieved by increasing the reaction time and minimizing the enzyme and modifier loading.
Such laccase-catalysed colorant can penetrate into the mass of wool fibres.

More recently, Munteanu et al. (2007) found that the cyclic voltammetry had a syneristic effect on wool staining using 2,2'-Azinobis(3-ethylbenzothiazoline6-sulfonate) (ABTS) enzymatic oxidation when coupled with ultrasound and resulted in higher colour depth (K/S value). The K/S value of staining wool in the system with the combination of cyclic voltammetry and ultrasonic irradiation was the sum of the values obtained in the presence of cyclic voltammetry and ultrasonic irradiation alone. However, the cumulative value was exceeded when wool colouration was carried out under continuous stirring and cyclic voltammetry, since mass transport of the active species to/from the working electrode was improved in the presence of ultrasound and formed a higher amount of $\mathrm{ABTS}^{2+}$ which was easily transported to the wool surface resulting in wool colouration.

When laccase (Denilite II S) was applied to modify the physical properties of wool fabric, Majid Montazer et al. (2009) found that the wool fabric changed colour, showing a redder and yellower colour with increasing laccase, due to the progressively higher oxidation of wool. Additionally, they found that the dyeing of laccase pre-treated wool fabric with madder gave a lower lightness since the laccase pretreated wool fabric was more hydrophilic and could adsorb higher amounts of water soluble dye in the dye bath. This suggested that the laccasebased pre-treatment was effective for fabric colouring when dyed with madder.

Hair dyeing. Hair is mostly proteinaceous in nature mainly consisting of fibrous $\alpha$-keratin proteins (Araújo et al. 2011). Hydrogen peroxide $\left(\mathrm{H}_{2} \mathrm{O}_{2}\right)$ and phenylenediamines are the most widely used oxidising agent and dye precursor for hair dyeing (Wall 1972), respectively. However, it has been recognized that the strong oxidation power of $\mathrm{H}_{2} \mathrm{O}_{2}$ under high alkalinity conditions causes severe hair damage (Araújo et al. 2011; Takada et al. 2003) and phenylenediamines are allergenic and carcinogenic (Chen et al. 2006; Marcoux et al. 2002; Huang et al. 2007). Therefore, it is high desirable to develop new approaches for hair dyeing to overcome these problems.

Various patents have claimed the oxidation dyeing of keratinous fibres and, in particular, human keratinous fibres (such as hair) in the presence of enzymes (Lang \& Cotteret 2007; Onuki et al. 2004). Oxidases such as peroxidase and laccase can be used to generate useful hair dyes. Laccase-based hair dyes are less irritant and easier to handle than current hair dyes (Aaslyng et al. 1997; Koike 2002; Lang \& Plos 
2002; Lang \& Cotteret 1999, 2004; Onuki et al. 2000; Pereira \& Burgaud 2005; Plos 2001, 2004a, b; Pruche et al. 2000; Shichiri et al. 2003; Riva 2006; Roure et al. 1992; Sorensen 2001; Tsuji et al. 2002; $\mathrm{Xu}$ 1999). However, phenylenediamines or other synthetic dye precursors which may be toxic to humans are still in use (Lang \& Cotteret 2007; Onuki et al. 2004).

Recently, Jeon et al. (2010) studied laccasecatalysed polymerization of natural phenols to form products for hair dyeing, overcoming the current problem with $\mathrm{H}_{2} \mathrm{O}_{2}$ - and phenylenediamine-based dyeing systems. They found that the novel combinations of natural phenols derived from edible plant fibres for polymeric dye synthesis can result in useful and diverse colours in hair dyeing. The colour of compounds obtained from two-monomer polymerizations was more diverse than that from singlemonomer polymerizations due to the formation of heteropolymer or homopolymer mixtures. Three kinds of two-monomer combinations, namely gallic acid/syringic acid, catechin/catechol and ferulic acid/ syringic acid, generated brown, black and red colourations, respectively, showing commercial value for grey hair dyeing. The catechin/catechol mixture could be particularly useful as an alternative to $p$-phenylenediamine for hair blackening, as both materials are natural polyphenols. The authors indicated that the laccase-catalysed polymerization of natural phenols to produce polymeric hair dyes would be a promising and applicable 'green' technology in the cosmetic industry.

\section{Conclusion and future outlook}

The potential of enzyme-based dyeing processes has been demonstrated in this review. Laccase and peroxidise, in particular, are able to catalyse the oxidative transformation or polymerization of various amine or phenolic compounds to generate coloured polymers 'in situ' to dye fabrics like cotton, flax, wool and hair. The enzymatic colouration takes place at low temperature, neutral $\mathrm{pH}$ and without pressure, addition of acid or alkaline products and toxic reagents. Moreover, biological colouration of lignocellulosic fibres allows elimination of the conventional bleaching process that uses alkaline conditions and other chemicals. Consquently, substitution of chemical processes with enzymes holds the promise of simpler, more economic and more environmentally friendly colouration processes. Additional functions, such as antioxidant antimicrobial activity, obtained through the attachment of polymers produced by enzymatic catalysis, can also add value to these products.
The discovery of novel laccases/peroxidases with different substrates specificities to extend the range of accessible colored compounds and discovery of more suitable, less polluting redox mediators remain as future challenges.

\section{Acknowledgments}

This work was supported by the Fundamental Research Funds for the Central Universities JUSRP211A02 and JUSRP21001; the Open Project Program of Key Laboratory of Eco-Textiles, Ministry of Education, Jiangnan University KLET1007 and the Open Project Program of State Key Laboratory for Modification of Chemical Fibers and Polymer Materials, DongHua University LK1005.

Declaration of interest: The authors report no conflicts of interest. The authors alone are responsible for the content and writing of the paper.

\section{References}

Aaslyng D, Rørbæk K, Sørensen NH. 1997. An ezyme for dying keratinous fibres. WO1997019998.

Abadulla E, Tzanov T, Costa S, Robra K, Cavaco-Paulo A, Gübitz GM. 2000. Decolorization and detoxification of textile dyes with a laccase from Trametes hirsuta. Appl Environ Microbiol 66:3357-3362.

AB enzymes[Internet]; 2011- [cited 2011 Sep 29]; Available from: http://www.abenzymes.com/index.php?section $=202 \&$ page $=2346$.

Adam W, Lazarus M, Saha-Möller CR, Weichhold O, Hoch U, Häring D, Schreier P. 1999. Advances in biochemical engineering/biotechnology. Berlin: Springer.

Aktas N, Kibarer G, Tanyolac A. 2000. Effects of reaction conditions on laccase-catalyzed $\alpha$-naphthol polymerization. J Chem Tech Biotechnol 75:840-846.

Aktas N, Tanyolac A. 2003. Kinetics of laccase-catalyzed oxidative polymerization of catechol. J Mol Catal B Enzym 22:61-69.

Alcalde M. 2007. Laccase: biological functions, molecular structure and industrial applications. In: Polaina J, Maccabe AP (eds) Industrial enzymes: structure, function and applications. Netherlands: Springer.

Amić D, Davidović-Amić D, Bešlo D, Trinajstić N. 2003. Structure-radical scavenging activity relationships of flavonoids. Croat Chem Acta 76:51-61.

Araújo R, Casal M, Cavaco-Paulo A. 2008. Application of enzymes for textile fibres processing. Biocatal Biotransfor 26:332-349.

Araújo R, Fernandes M, Cavaco-Paulo A, Gomes A. 2011. Biology of human hair: know your hair to control it. Adv Biochem Eng Biotechnol 125:121-143.

Ardon O, Kerem Z, Hadar Y. 1996. Enhancement of laccase activity in liquid cultures of the ligninolytic fungus Pleurotus ostreatus by cotton stalk extract. J Biotechnol 51:201-207.

Azevedo AM, Martins VC, Prazeres DM, Vojinović V, Cabral JM, Fonseca LP. 2003. Horseradish peroxidase: a valuable tool in biotechnology. Biotechnol Annu Rev 9:199-247. 
Bach A, Chodat R. 1903. Untersuchungen über die Rolle der Peroxyde in der Chemie der lebenden Zelle. IV. Ueber Peroxydase. Ber Deutsch Chem Gesell 36:600-605.

Baldrian P. 2006. Fungal laccases: occurrence and properties. Fems microbiol rev 30:215-242.

Banci L. 1997. Structural properties of peroxidases. J Biotechnol 53:253-263.

Banci L, Ciofi-Baffoni S, Tien M. 1999. Lignin and Mn peroxidase-catalyzed oxidation of phenolic lignin oligomers. Biochem 38:3205-3210.

Barfoed M, Kirk O. 1999. Enzymatic method for overdyeing warp dyed denim textiles: US Patent 5925148.

Barreca AM, Sjögren B, Fabbrini M, Galli C, Gentili P. 2004 Catalytic efficiency of some mediators in laccase-catalyzed alcohol oxidation. Biocatal Biotransfor 22:105-112.

Basto C, Tzanov T, Cavaco-Paulo A. 2007. Combined ultrasoundlaccase assisted bleaching of cotton. Ultrason Sonochem 14: 350-354.

Battistuzzi G, Belleia M, Bortolottia CA, Sola M. 2010. Redox properties of heme peroxidases. Arch Biochem Biophys 500:21-36.

Benfield G, Bocks SM, Bromley K, Brown BR. 1964. Studies of fungal and plant laccases. Phytochemistry 3:79-88.

Bertrand G. 1894. Sur le latex de l'arbre à laque. CR Hebd Acad Sci (Paris) 118:1215-1218.

Bille J, Phyllis GT. 1997. Understanding Textiles. 6th edition, New Jersey, USA: Prentice Hall.

Blanco CD, González MD, Monmany JMD, Tzanov T. 2009. Dyeing properties, synthesis, isolation and characterization of an in situ generated phenolic pigment, covalently bound to cotton. Enzym Microb Tech 44:380-385.

Bourbonnais R, Paice MG. 1990. Oxidation of non-phenolic substrates: an expanded role for laccase in lignin biodegradation. FEBS Lett. 267:99-102.

Bourbonnais R, Paice MG. 1992. Demethylation and delignification of kraft pulp by Trametes versicolor laccase in the presence of 2, 2'-azinobis-(3-ethylbenzthiazoline-6-sulphonate). Appl Microbiol Biotechnol 36:823-827.

Bourbonnais R, Paice MG, Reid ID, Lanthier P, Yaguchi M. 1995. Lignin oxidation by laccase isozymesfrom trametes ersicolor and role of the mediator 2,2'-azi-nobis (3-ethylbenzthiazoline-6-sulfonate) in kraft lignin depolymerization. Appl Environ Microbiol 61:1876-1880.

Bourbonnais R, Paice MG, Freiermuth B, Bodie E, Borneman S. 1997. Reactivities of various mediators and laccases with kraft pulp and lignin model compounds. Appl Environ Microbiol 63:4627-4632.

Burton SG. 2003. Laccases and phenol oxidases in organic synthesis-a review. Curr org chem 7:1317-1331.

Calafell M, Diaz C, Hadzhiyska H, Gibert JM, Daga JM, Tzanov T. 2007. Bio-catalyzed coloration of cellulose fibers. Biocatal Biotransform 25:336-340.

Call HP, Mücke I. 1997. History, overview and applications of mediated lignolytic systems, especially laccase-mediatorsystems (Lignozym ${ }^{\circledR}$-process). J Biotechnol 53:163-202.

Camarero S, Ibarra D, Martinez MJ, Martinez AT. 2005. Ligninderived compounds as efficient laccase mediators for decolorization of different types of recalcitrant dyes. Appl Environ Microbiol 71:1775-1784.

Campos R, Cavaco-Paulo A, Robra KH. 2001a. Indigo degradation with laccases from Polyporus sp. and Sclerotium rolfsii. Text Res J 71:420-424.

Campos R, Kandelbauer A, Robra KH, Cavaco-Paulo A, Gübitz G. 2001b. Indigo degradation with purified laccases from Trametes hirsuta and Sclerotium rolfsii. J Biotechnol 89:131-139.

Cavaco-Paulo A, Morgado J, Almeida, L, Kilburn D. 1998. Indigo backstaining during cellulase washing. Text Res J 68:398-401.
Chen SC, Chen CH, Chen CL, Hsu LS, Huang YC, Chung KT, Chye SM. 2006. P-Phenylenediamineinduces p53-mediated apoptosis in Mardin-Darby canine kidney cells. Toxicol Vitro 20:801-807.

Claus H. 2003. Laccases and their occurrence in prokaryotes. Arch Microbiol 179:145-150.

Claus H. 2004. Laccases: structure, reactions, distribution. Micron 35:93-96.

Claus H, Faber G, Konig H. 2004. Redox-mediated decolorization of synthetic dyes by fungal laccases. Appl Microbiol Biotechnol 59:672-678.

Clifford P. 1986. The dyeing of cellulosic fibers. London: Dyers' Company Publications Trust, Society of Dyers and Colourists.

Chhagani RR, Iyer V, Shenai VA. 2000. Modifying cotton for dyeing. Colourage 47:27-32.

Cole JL, Clarke PA, Solomon EI. 1990. Spectroscopic and chemical studies of the laccase trinuclear copper active site: geometric and electronic structure. J Am Chem Soc 112: 9534-9548.

Conesa A, Punt PJ, van den Hondel CAMJJ. 2002. Fungal peroxidases: molecular aspects and applications. J Biotechnol 93:143-158.

Couto SR, Toca-Herrera JL. 2006. Lacasses in the textile industry. Biotechnol Mol Biol Rev 1:115-120.

Craven MR, Ledward DA, Taylor AJ. 1981. The production and analysis of food colourants derived from vegetable material. J Sci Food Agr 32:847-848.

Crestini CL, Argyropoulos DS. 1998. The early oxidative biodegradation steps of residual kraft lignin models with laccase. Bioorg Med Chem 6:2161-2169.

David C, Daro A, Szalai E, Atarhouch T, Mergeay M. 1996. Formation of polymeric pigment in presence of bacteria and comparison with chemical oxidative coupling- . Catabolism of tyrosine and hydroxyl-phenylacetic acid by Alcaligenes eutrophuc CH 34 and mutants. Eur Polymer J 32:669-679.

de Montellano PRO, Crab LA. 1987. Co-oxidation of styrene by horseradish peroxidase and phenols: a biochemical model for protein-mediated co-oxidation. Biochemistry 26: $5310-5314$

Desai SS, Nityanand C. 2011. Microbial laccases and their applications: a review. Asian J Biotechnol 3:98-124.

d'Ischia M, Napolitano A, Prota G. 1991. Peroxidase as an alternative to tyrosinase in the oxidative polymerization of 5,6dihydroxyindoles to melanin(s). Biochim Biophys Acta 1073: 423-430.

Dubey S, Singh D, Misra RA. 1998. Enzymatic synthesis and various properties of poly(catechol). Enzym Microb Tech 23:432-437.

Dunford HB. 1999. Heme Peroxidases. Chichester: John Wiley.

Dunford HB, Stillman JS. 1976. On the function and mechanism of action of peroxidases. Coord Chem Rev 19:187-251.

Durán N, Esposito E. 2000. Potential applications of oxidative enzymes and phenoloxidase-like compounds in wastewater and soil treatment: a Review. Appl Catal B Environ 28:83-99.

Durán N, Rosa MA, D’Annibale A, Gianfreda L. 2002. Applications of laccases and tyrosinases (phenoloxidases) immobilized on different supports: a review. Enzym Microb Tech 31: 907-931.

Dwivedi UN, Singh P, Pandey VP, Kumar A. 2011. Structurefunction relationship among bacterial, fungal and plant laccases. J Mol Catal B Enzym 68:117-128.

Eggert C, Temp U, Dean JFD, Eriksson KEL. 1996a. A fungal metabolite mediates degradation of non-phenolic lignin structures and synthetic lignin by laccase. FEBS Lett 391:144-148. 
Eggert C, Temp U, Eriksson KE. 1996b. Laccase-producing white-rot fungus lacking lignin peroxidase and manganese peroxidase. Acs Symp Ser 655:130-150.

Enaud E, Trovaslet M, Bruyneel F, Billottet L, Karaaslan R, Sener ME, Coppens P, Casas A, Jaeger IJ, Hafner C, Onderwater RCA, Corbisier AM, Marchand-Brynaert J, Vanhulle S. 2010. A novel azoanthraquinone dye made through innovative enzymatic process. Dyes Pigments 85:99-108.

English AM. 1994. Encyclopedia of Inorganic Chemistry: iron: heme proteins, peroxidases and catalases. In: King RB (Ed) Encyclopedia of inorganic chemistry. Chichester: Wiley.

English AM, Tsapralis G. 1995. Catalytic structure-function relationships in heme peroxidases. Adv Inorg Chem 43:79-125.

Evans CS, Hedger JN. 2001. Degradation of plant cell wall polymers. In: Gadd GM (ed) Fungi in bioremediation. British Mycological Society. United Kingdom: Cambridge Univ Press.

Everse J, Everse KE. 1991. Peroxidases in chemistry and biology. Boca Raton: CRC Press.

Flickinger MC, Drew SW. 1999. Encyclopedia of bioprocess technology: fermentation, biocatalysis and bioseparation. Biocatalysis and bioseparation, New York, USA: John Willy \& Sons. pp. $1545-1554$.

Forte S, Polak J, Valensin D, Taddei M, Basosi R, Vanhulle S, Jarosz-Wilkolazka A, Pogni R. 2010. Synthesis and structural characterization of a novel phenoxazinone dye by use of a fungal laccase. J Mol Catal B Enzym 63:116-120.

Friedman M. 1996. Food browning and its prevention: an overview. J Agr Food Chem 44:631-53.

Galli C, Gentili P. 2004. Chemical messengers: mediated oxidations with the enzyme laccase. J Phys Org Chem 17:973-977.

Gianfreda, L, Xu F, Bollag J-M. 1999. Laccases: a useful group of oxidoreductive enzymes. Bioremediation J 3:1-26.

Gianfreda L, Sannino F, Rao MA, Bollag JM. 2003. Oxidative transformation of phenols in aqueous mixtures. Water Res 37:3205-3215.

Gray JS, Montgomery R. 1997. The N-glycosylation sites of soybean seed coat peroxidase, Glycobiology 7:679-685.

Guimarães C, Kim S, Silva C, Cavaco-Paulo A. 2011. In situ laccase-assisted overdyeing of denim using flavonoids. Biotechnol J doi: 10.1002/biot.201100201.

Gumiero A, Murphy EJ, Metcalfe CL, Moody PCE, Raven EL. 2010. An analysis of substrate binding interactions in the heme peroxidase enzymes: a structural perspective. Arch Biochem Biophys 500:13-20.

Gutiérrez A, del Río JC, Ibarra D, Rencoret J, Romero J, Speranza M, Camarero S, Martínez MJ, Martínez AT. 2006. Environ Sci Tech 40:3416-3422.

Hadzhiyska H, Calafell M, Gibert JM, Dagà JM, Tzanov T. 2006. Laccase-assistant dyeing of cotton. Biotechnol Lett 28:755-759.

Hammel KE, Moen MA. 1991. Depolymerization of a synthetic lignin in vitro by lignin peroxidase. Enzym Microb Tech 13: 15-18.

Hammel KE. 1996. Extracellular free radical biochemistry of ligninolytic fungi. New J Chem 20:195-198.

Hedin PA, Jenkis JN, Parrot WL. 1992. Evaluation of flavonoids in Gossypium arboretum (L.) cottons as potential source of resistance to tobacco budworm. J Chem Ecol 18:105-114.

Hewson WD, Dunford B. 1976a. Oxidation of p-cresol by horseradish peroxidase compound I. J Biol Chem 251:6036-6042.

Hewson WD, Dunford B. 1976b. Stoichiometry of the reaction between horseradish peroxidase and p-cresol. J Biol Chem 251:6043-6052.

Hoegger PJ, Kilaru S, James TY, Thacker JR, Kües U. 2006. Phylogenetic comparison and classification of laccase and related multicopper oxidase protein sequences. FEBS J 273: $2308-2326$.
Hoff T, Liu SY, Bollag JM. 1985. Transformation of halogen-, alkyl-, and alkoxy-substituted anilines by a laccase of trametes versicolor. Appl Environ Microbiol 49:1040-1045.

Huang YC, Hung WC, Kang WY, Chen WT, Chai CY. 2007. Phenylenediamine induced DNA damage in SV-40 immortalized human uroepithelial cells and expression of mutant p53 and COX-2 proteins. Toxicol Lett 170:116-123.

Jeon JR, Kim EJ, Murugesan K, Park HK, Kim YM, Kwon JH, Kim WG, Lee JY, Chang YS. 2010. Laccase-catalysed polymeric dye synthesis from plant-derived phenols for potential application in hair dyeing: enzymatic colourations driven by homo- or hetero-polymer synthesis. Microbial Biotechnol 3:324-335.

Johannes C, Majcherczyk A. 2000. Natural mediators in the oxidation of polycyclic aromatic hydrocarbons by laccase mediator systems. Appl Environ Microbiol 66:524-528.

Kalmis E, Yasa I, Kalyoncu F, Pazarbasi B, Kocyigit A. 2008. Ligninolytic enzyme activities in mycellium of some wild and commercial mushrooms. Afr J Biotechnol 7:4314-4320.

Kawai S, Nakagawa M, Ohashi H. 1999. Aromatic ring cleavage of a non-phenolic L-O-4 lignin model dimer by laccase of Trametes versicolor in the presence of 1-hydroxybenzotriazole. FEBS Lett 446:355-358.

Kay E, Shannon LM, Lew JY. 1967. Peroxidase isozymes from horseradish roots. J Biol Chem 242:2470-2473.

Kersten PJ, Kalyanaraman B, Hammel KE, Reinhammar B, Kirk YK. 1990. Comparison of lignin peroxidase, horseradish peroxidase and laccase in the oxidation of methoxybenzenes. Biochem J 268:475-480.

Kim S. 2009. Modification of cellulosic fibres using oxidoreductases. Doctoral Thesis. Textile Engineering Department. Universidade de Minho.

Kim S, Cavaco-Paulo A. 2011. Laccase-catalysed proteinflavonoid conjugates for flax fibre modification. Appl Microbiol Biotechnol. DOI 10.1007/s00253-011-3524-8.

Kim S, Moldes D, Cavaco-Paulo A. 2007a. Laccases for enzymatic colouration of unbleached cotton. Enzym Microb Tech 40:1788-1793.

Kim S, Silva C, Evtuguin DV, Gamelas JAF, Cavaco-Paulo A. 2011. Polyoxometalate laccase-mediated oxidative polymerization of catechol for textile dyeing. Appl Microbiol Biotechnol 89:981-987.

Kim S, Silva C, Zille A, Lopez C, Evtuguin DV, Cavaco-Paulo A. 2009. Characterisation of enzymatically oxidised lignosulfonates and their application on lignocellulosic fabrics. Polymer Int 58:863-868.

Kim S, Zille A, Murkovic M, Gübitz G., Cavaco-Paulo A. 2007b. Enzymatic polymerization on the surface of functionalized cellulose fibers. Enzym microb Tech 40:1782-1787.

Kim S, Zille A, Vasconcelos A, Cavaco-Paulo A. 2007c. New developments of enzymatic treatments on cellulosic fibers. In: Eggleston G and Vercellotti JR (Eds.) Industrial Application of Enzymes on Carbohydrate-Based Material. ACS SYMPOSIUM SERIES 972, Washington, DC: American Chemical Society, pp. 186-194.

Kobayashi S, Higashimura H. 2003. Oxidative polymerization of phenols revisited. Progr colloid Polymer Sci 28:1015-1048.

Kobayashi S, Uyama H, Kimura S. 2001. Enzymatic polymerization. Chem Rev 101:3793-3818.

Koike K. 2002. Multiple agent type hair dye. JP2002255764.

Koroljova-Skorobogat'ko OV, Stepanova EV, Gavrilova VP, Morozova OV, Lubimova NV, Dzchafarova AN, Jaropolov AI, Makower A. 1998. Purification and characterization of the constitutive form of laccase from the basidiomycete Coriolus hirsutus and effect of inducers on laccase synthesis. Biotechnol Appl Biochem 28:47-54 
Kudanga T, Nyanhongo GS, Gübitz GM, Burton S. 2011. Potential applications of laccase-mediated coupling and grafting reactions: a review. Enzym Microb Tech 48:195-208.

Kumar R, Watterson A, Pamae VS, Kumar J, Samuelson LA. 2005. Enzymatic synthesis of polymers. US 6962963.

Kunamneni A, Camarero S, Garcia-Burgos C, Plou FJ, Ballesteros A, Alcalde M. 2008a. Engineering and applications of fungal laccases for organic synthesis. Microb Cell Fact 7:32-48.

Kunamneni A, Plou FJ, Ballesteros A, Alcalde M. 2008b. Laccases and their applications a patent review. Recent Pat Biotechnol $2: 10-24$.

Kuhad RC, Singh A, Eriksson KEL. 1997. Biotechnology in the pulp and paper industry. In: Eriksson K-EL (Ed) Advances in biochemical engineering biotechnology. Berlin: Springer. 57.

Lang G, Cotteret J. 1999. Hair dye composition containing a laccase. (L'Oreal, Fr.). Int Pat Appl WO9936036.

Lang G, Cotteret J. 2004. Composition for the oxidation dyeing of keratinous fibres containing a laccase and dyeing method using this composition: US2004255401 A1.

Lang G, Cotteret J. 2007. Composition for the oxidation dyeing of keratinous fibers containing a laccase and dyeing method using this composition. US patent $7175673 \mathrm{~B} 2$

Lang G, Plos G. 2002. Enzyme composition for bleaching human keratinous fibres and bleaching method: WO2002007687 A1.

Leontievsky AA, Vares T, Lankinen P, Shergill JK, Pozdnyakova NN, Myasoedova NM, Kalkkinen N, Golovleva LA, Cammack R, Thurston CF, Hatakka A. 1997. Blue and yellow laccases of ligninolytic fungi. FEMS Microbiol Lett 156:9-14.

Li K, Xu F, Erikssen KEL. 1999. Comparison of fungal laccases and redox mediators in oxidation of a non-phenolic lignin model compound. Appl Environ Microbiol 65:2654-2660.

Lorenzo M, Matthias HR, Silvia SB, Helmut R. 2002. New Polymers from Natural Phenols Using Horseradish or Soybean Peroxidase. Macromol Biosci 2:24-32.

Maciel MJM, Silva ACE, Ribeiro HCT. 2010. Industrial and biotechnological applications of ligninolytic enzymes of the basidiomycota: a review. Electron J Biotechnol 13:1-12.

Makris D, Rossiter J. 2002. An investigation on structural aspects influencing product formation in enzymic and chemical oxidation of quercetin and related flavonols. Food Chem 77:177-185.

Marcoux D, Couture-Tridel PM, Riboulet-Delmas G, Sasseville D. 2002. Sensitization to para-phenylenediamine from a streetside temporary tattoo. Pediatr Dermatol 19:498-502.

Maryan AS, Montazer M. 2009. The effect of cellulase and laccase enzymes on denim color. J Color Sci Technol 3:53-64.

Mayer AM, Staples RC. 2002. Laccase: new functions for an old enzyme. Phytochem 60:551-565.

Messerschmidt A. 1994. Blue copper oxidases. Adv Inorg Chem 40:121-185.

Messerschmidt A, Huber R. 1990. The blue oxidases, ascorbate oxidase, laccase and ceruloplasmin. Modelling and structural relationships. Eur J Biochem 187:341-352.

Mikolasch A, Schauer F. 2009. Fungal laccases as tools for the synthesis of new hybrid molecules and biomaterials. Appl Microbiol Biotechnol 82:605-624.

Miranda MV, Magri ML, del Cañizo AAN, Cascone O. 2002. Study of variables involved in horseradish and soybean peroxidase purification by affinity chromatography on concanavalin A-Agarose. Process Biochem 38:537-543.

Mita N, Tawaki S, Uyama H, Kobayashi S. 2003. Laccasecatalyzed oxidative polymerization of phenols. Macromol Biosci 3:253-257.

Mohamed SA, Abulnaja KO, Ads AS, Khan JA, Kumosani TA. 2011. Characterisation of an anionic peroxidase from horseradish cv. Balady. Food Chem 128:725-730.

Mohorcic M, Friedrich J, Pavko A. 2004. Decoloration of the diazo dye reactive black 5 by immobilised Bjerkandera adusta in a stirred tank bioreactor. Acta Chimica Slovenica 51: 619-628.

Montazer M, Maryan AS. 2008. Application of laccases with cellulases on denim for clean effluent and repeatable biowashing. J Appl Polymer Sci 110:3121-3129.

Montazer M, Dadashian F, Hemmatinejad N, Farhoudi K. 2009. Treatment of wool with laccase and dyeing with madder. Appl Microbiol Biotechnol 158:685-693.

Morozova OV, Shumakovich GP, Shleev SV, Iaropolov AI. 2007. Laccase-mediator systems and their applications: a review. Prikl Biokhim Mikrobiol 43:583-597.

Munteanu FD, Basto C, Gubitz GM, Cavaco-Paulo A. 2007. Staining of wool using the reaction products of ABTS oxidation by laccase synergetic effects of ultrasound and cyclic voltammetry. Ultroson Sonochem 14:363-367.

Mustafa R, Muniglia L, Rovel B, Girardin M. 2005. Phenolic colorants obtained by enzymatic synthesis using a fungal laccase in a hydro-organic biphasic system. Food Res Int 38:995-1000.

Nakayama T, Amachi T. 1999. Fungal peroxidase: its structure, function, and application. J Mol Catal B 6:185-198.

Nigel CV. 2004. Horseradish peroxidase: a modern view of a classic enzyme. Phytochemistry 65:249-259.

Nyanhongo GS, Prasetyo EN, Kudanga T, Gübitz G. 2010. Grafting of functional molecules: insights into peroxidasederived materials. In: Torres E, Ayala M (Eds) 'Biocatalysis based on heme peroxidases: peroxidases as potential industrial biocatalysts' 1st Edition. Berlin Heidelberg: Springer-Verlag. pp. $155-178$

Onuki T, Nogucji M, Mitamura J. 2000. Oxidative hair dye composition containing laccase. WO0037030.

Onuki T, Noguchi M, Mitamura J. 2004. Hair dyeing compositions. EP patent $1142561 \mathrm{~A} 1$.

Pazarloglu NK, Sariisik M, Telefoncu A. 2005. Laccase: production by trametes versicolor and application to denim washing. Process Biochem 40:1673-1678.

Pereira L, Bastos C, Tzanov T, Cavaco-Paulo A, Gübitz GM. 2005. Environmentally friendly bleaching of cotton using laccases. Environ Chem Lett 3:66-69.

Pereira R, Burgaud H. 2005. Producing tetraazapentamethine compounds comprises reacting an azine compound with an oxidizing agent, useful for dyeing keratinic fibers, e.g. hair. FR 2863487 A1.

Pilz R, Hammer E, Schauer F, Kragl U. 2003. Laccase-catalysed synthesis of coupling products of phenolic substrates in different reactors. Appl Microbiol Biotechnol 60:708-712.

Plos G. 2001. Composition for oxidative dyeing of keratinous fibres and dyeing process using same. EP1138318 A2.

Plos G. 2004a. Composition for dyeing keratin fibres, comprising at least one free-radical compound of nitroxyl type and at least one primary or secondary alcohol. WO2004056331 A1.

Plos G. 2004b. Composition for oxidation dyeing of keratinic fibers, e.g. human hair, comprises a nitroxyl radical. FR2848836 A1

Pogni R, Valensin D, Jarosz-Wilkolazka A, Parisi ML, Basosi R. 2010. Synthesis, structural characterization and LCA analysis of a novel phenoxazinone dye by use of a fungal laccase. J Biotechnol 150:195-195.

Polak J, Jarosz-Wilkolazka A. 2010. Whole-cell fungal transformation of precursors into dyes. Microb Cell Fact 9:51-62.

Poulos TL. 1993. Peroxidases. Curr Opin Biotechnol 4:484-489.

Pruche F, Saint LP, Bernards B. 2000. Hydroxysitilbene compounds of formula (I) used as components in oxidation dye systems especially for dyeing hair. EP1013260.

Reinhammar D. 1984. In Copper proteins and copper enzymes. Boca Raton: CRC Press.

Reihmann M, Ritter H. 2006. Synthesis of phenol polymers using peroxidases. Adv Polymer Sci 194:1-49. 
Reyes P, Pickard MA, Vazquez-Duhalt R. 1999. Hydroxybenzotriazole increases the range of textile dyes decolorized by immobilized laccase. Biotechnol Lett 21:875-880.

Riva S. 2006. Laccases blue enzymes for green chemistry. Trends Biotechnol 24:219-226.

Robles A, Lucas R, De Cienfuegos AG, Galvez A. 2000. Phenoloxidase (laccase) activity in strain of the hyphomycete Chalara paradoxa isolated from olive mill wastewater disposal ponds. Enzym Microb Tech 26:484-490.

Roure M, Delattre P, Froger H.1992. Composition for an enzymic coloration of keratin fibres, especially for hair and its use in a dyeing process. EP0504005.

Ryan BJ, Carolan N, Ó'Fágáin C. 2006. Horseradish and soybean peroxidases: comparable tools for alternative niches? Trends Biotechnol 24:355-363.

Sakurai T. 1992. Anaerobic reactions of Rhus vernicifera laccase and its type- 2 copper-depleted derivatives with hexacyanoferrate (II). Biochem J 284:681-685.

Shichiri S, Morita K, Koike K. 2003. Hair cosmetic. JP2003055175 A2.

Shin H, Gübitz G, Cavaco-Paulo A. 2001. 'In Situ' Enzymatically Prepared Polymers for Wool Coloration. Macromol Mater Eng 286:691-694.

Silva C, Matamá T, Kim SY, Padrão J, Prasetyo EN, Kudanga T, Nyanhongo GS, Gübitz GM, Casal M, Cavaco-Paulo A. 2011. Antimicrobial and antioxidant linen via laccase-assisted grafting. React Funct Polym 71:713-720.

Smith AT, Veitch NC. 1998. Substrate binding and catalysis in heme peroxidases. Curr Opin Chem Biol 2:269-278.

Solomon EI, Baldwin MJ, Lowery MD. 1992. Electronic structure of active sites in copper proteins: contributions to reactivity. Chem Rev 92:521-542.

Solomon EI, Sundaram UM, Machonkin TE. 1996. Multicopper oxidases and oxygenases. Chem Rev 96:2563-2606.

Sorensen NH. 2001. Method for dyeing dry hair. WO2001068042 A1.

Takada K, Nakamura A, Matsuo N, Inoue A, Someya K, Shimogaki H. 2003. Influence of oxidative and/or reductive treatment on human hair (I): analysis of hair-damage after oxidative and/or reductive treatment. J Oleo Sci 52:541-548.

Tawaki S, Uchida Y, Maeda Y, Ikeda I. 2005. HRP-catalyzed polymerization of sugar-based phenols in aqueous organic solvents. Carbohydr Polymer 59:71-74.

Taylor AJ, Clydesdale FM. 1987a. Potential of oxidised phenolics as food colourants. Food Chem 24:301-313.

Taylor AJ, Clydesdale FM. 1987b. Assessment of tinctorial power of food colourants. Food Chem 26:1-10.

Thurston CF. 1994. The structure and function of fungal laccases. Microbiol 140:19-26.

Tsubokawa N, Iida T, Takayama TJ. 2000. Modification of cellulose powder surface by grafting of polymers with controlled molecular weight and narrow molecular weight distribution. Appl Polymer Sci 75:515-22.

Tsuji K, Yoshino T, Asai Y. 2002. Composition for bleaching melamine. JP2002012535 A2.

Tzanov T, Basto C, Gübitz GM, Cavaco-Paulo A. 2003a. Laccases to improve the whiteness in a conventional: bleaching of cotton. Macromol Mater Eng 288:807-810.
Tzanov T, Silva CJ, Zille A, Oliveira J, Cavaco-Paulo A. 2003b. Effect of some process parameters in enzymatic dyeing of wool. Appl Biochem Biotechnol 111:1-13.

Uyama H, Kobayashi S. 2002. Enzyme-catalyzed polymerization to functional polymers. J Mol Catal B Enzym19-20: $117-127$.

Van Aken B, Agathos SN. 2001. Biodegradation of nitrosubstituted explosives by ligninolytic white-rot fungi: a mechanistic approach. Adv Appl Microbiol 48:1-77.

Van Aken B, Agathos SN. 2002. Implication of manganese (III), oxalate, and oxygen in the degradation of nitroaromatic compounds by manganese peroxidase $(\mathrm{MnP})$. Appl Microbiol Biotechnol 58:345-351.

Van Deurzen MPJ, van Rantwijk F, Sheldon RA. 1997. Selective oxidations catalyzed by peroxidases. Tetrahedron 53: 13183-13220.

Veitch NC, Smith AT. 2001. Horseradish peroxidase. Adv Inorg Chem 51:107-162.

Wall FE. 1972. Bleaches, hair colorings, and dye removers. In: chapter 23: Cosmetics: science and technology, 2nd edition. New York, USA: Academic press.

Widsten P, Kandelbauer A. 2008. Laccase applications in the forest products industry: a review. Enzym Microb Tech 42: 293-307.

Wong Y, Yu J. 1999. Laccase-catalyzed decolorization of synthetic dyes. Water Res 33:3512-3520.

Worthington. 2011. Peroxidase. [Internet]; 2011- [cited 2011 Sep 29]; Available from: http://www.worthington-biochem. com/HPO/default.html.

Xu F. 1996. Oxidation of phenols, anilines, and benzenethiols by fungal laccases: correlation between activity and redox potentials as well as halide inhibition. Biochemistry 35:7608-7614.

Xu F. 1999. Recent progress in laccase study: properties, enzymology, production, and applications: The encyclopedia of bioprocessing technology: fermentation, biocatalysis, and bioseparation. New York: John Wiley \& Sons.

Xu F, Kulys JJ, Duke K, Li K, Krikstopaitis K, Deussen HJ, Abbate E, Galinyte V, Schneider P. 2000. Redox chemistry in laccase-catalyzed oxidation of N-hydroxy compounds. Appl Environ Microbiol 66:2052-2056.

Xu F, Shin W, Brown SH, Wahleithner JA, Sundaram UM, Solomon EI. 1996. A study of a series of recombinant fungal laccases and bilirubin oxidase that exhibit significant differences in redox potential, substrate specificity, and stability. Biochim Biophys Acta 1292:303-311.

Yaropolov AI, Skorobogat'ko OV, Vartanov SS, Varfolomeev SD. 1994. Laccase: Properties, catalytic mechanism, and applicability. Appl Biochem Biotechnol 49:257-280.

Yoshida H. 1883. Chemistry of Lacquer (Urishi) part 1. J Chem Soc (Tokyo) 43:472-486.

Zhou Q, Greffe L, Baumann MJ, Malmstrom E, Teeri TT, Brumer III H. 2005. Use of xyloglucan as a molecular anchor for the elaboration of polymers from cellulose surfaces: a general route for the design of biocomposites. Macromolecules 38: 3547-3549.

Zille A. 2005. Laccase reactions for textile applications. PhD Thesis. Universidade de Minho, Portugal. 